\title{
Soil erosion in Mediterranean chestnut tree plantations at risk due to climate change and land abandonment
}

\author{
Jesús Barrena-González ${ }^{1 *}$, Javier Lozano-Parra² ${ }^{2}$ Alberto Alfonso-Torreño ${ }^{1}$, \\ Carlos Lozano-Fondón ${ }^{3}$, Mohamed Amine Abdennour ${ }^{4}$, \\ Artemi Cerdà ${ }^{5}$ and Manuel Pulido-Fernández ${ }^{1}$
}

${ }^{1}$ INTERRA Research Institute, University of Extremadura, Avenida de la Universidad s/n, 10071 Cáceres, Spain
${ }^{2}$ Institute of Geography, Pontificia Universidad Católica de Chile, Avda, Vicuña Mackenna 4860, Santiago de Chile, Chile
${ }^{3}$ University of Parma, Life Sciences and Environmental Sustainability, Park Area of Sciences 11/a, 43124 Parma, Italy
${ }^{4}$ University of Mohamed Khider of Biskra, Faculty of Natural Sciences and Life, O7000 Biskra, Algeria
${ }^{5}$ University of Valencia, Soil Erosion and Degradation Research Group (SEDER), Blasco Ibañez 28, 46010-Valencia, Spain

\begin{abstract}
Chestnut cultivation is a type of traditional centennial exploitation in southern areas of Extremadura. Currently, chestnut is in danger of extinction due to the effects of climate change, some diseases (e.g. Cryphonectria parasitica) and land mismanagement. The high temporal variability of rainfall leads to soil erosion in chestnut cultivation. New forms of management are proposed to try, among other things, to reduce soil losses. This study quantifies soil losses in areas under tree canopies and open areas considering two different age plantations; 1990s and 1960s. To achieve the proposed goal 18 erosion plots were installed as paired plots under tree canopies and open areas in both plantations. The total amount of rainfall per event, tree cover, bare soil, runoff coefficient and sediment concentration were also measured in every plot. The results showed that the highest percentage of bare soil ( $>45 \%)$ coincides with the period of greatest tree cover $(>75 \%)$. The open areas and the youngest plantation showed soil losses higher than the areas under the tree and the oldest plantation. In addition, soil losses increase as higher percentages of bare soil are recorded. We conclude that the size of the trees and a better soil stability in older plantations help reduce soil losses.
\end{abstract}

Key words: soil losses; land management; rural areas; traditional crops; sustainability

Editor: Bohdan Konôpka

\section{Introduction}

There are many theories relating to the origin of chestnut trees but no clear evidence has appeared yet about the existence of this species in Europe. Some authors are frequently considering that a natural origin of chestnut trees exists in eastern Europe (Martín et al. 2007). Something similar happens in the Iberian Peninsula with the natural origin of this specie. The hypothesis most accepted has been an introduction by the human bounded to the stage of the Roman Empire during the reconquest (Conedera \& Krebs 2007). Nevertheless, some recent researches have shown the presence of chestnut trees before to the Roman era (Pulido et al. 2007).

In Europe, the chestnut tree can be found in many countries. France occupies the first position followed by Italy and Spain (Conedera et al. 2016). Also, the presence of this specie involves that the sweet chestnut (Castanea sativa) industry have a great economic potential in some countries in Europe (Centeno et al. 1998). The chestnut tree appears in Iberian Peninsula in almost all territory (Conedera et al. 2016), especially in areas in which accumulated rainfall is above to $1,000 \mathrm{~mm} \mathrm{y}^{-1}$ within an altitudinal range between 500 and $1,200 \mathrm{~m}$, with a cultivated area of 36,682 ha. The largest area of chestnut trees is in Galicia (24,592 ha) followed by Andalusia ( $8,856 \mathrm{ha}$ ) and Extremadura (2,481 ha) according to the Ministry of Agriculture, Fisheries and Food in 2018. In Extremadura, the chestnut trees are mainly located in mountain areas due to weather conditions.

The chestnut trees crop has had a large tradition in Europe since Roman period until today (Conedera et al. 2004), hence the extension of this crop occupies the most varied range of landscapes and soils. Acid soils are the best pedological type for the development of chestnuts since it has low clay content and a high percentage of organic matter (Berrocal 1998). Currently, traditional

*Corresponding author.Jesús Barrena-González, e-mail:jesusbarrena@unex.es 
grafted and ungrafted species (e.g. reboldos chestnut) coexist in the region of Extremadura (Martín et al. 2017). Chestnut trees, like other arboreal species, suffer from diseases that involve a huge degradation of the plant and, in many cases, death. For many years the chestnut trees have been suffering two types of diseases, mainly in Extremadura, like chestnut blight (Cryphonectria parasitica) and the ink disease (Phytophthora cinnamomi) (González et al. 2013). Moroever the continuous abandonment of crops in rural areas (MacDonald et al. 2000; Renwick et al. 2013) and the context of climate change in the southern areas, the threats of disappearance is multiplied considerably.

But, can abandonment of chestnut cultivation prove beneficial in other environmental aspects? Considering that the chestnut trees are located on slopes more than $15 \%$, with bare soil most of theyear coupled with previous agricultural activities, the reduction of some erosive processes may be effective as shown in other studies (GarcíaRuiz 2010). In these areas where there has been a human substitution of shrub species such as Cistus ladanifer, re-colonization is the most probable scenario in case agricultural activities is abandoned.

At this time, when there seems to be a high awareness of the effects that climate change (Meira Cartea 2007) can have, we should rethink the forms of land use in each of the possible environments in which all agricultural activities are developed. One of the main lines of action is to reduce soil erosion rates. This action appears as one of the United Nations Sustainable Development Goals (Griggs et al. 2013; Keesstra et al. 2016) in the face of the progress of desertification processes and events of torrential rains increasingly common (Dregne 1986; Millán et al. 2005).

There are many published works on the quantification and monitoring of soil erosion in agricultural land (Pimentel et al. 1995; Lal 2001; Montgomery 2007). Often, these studies try not only to quantify soil losses but also aspects such as their effects on multiple soil functions (Doran \& Zeiss 2000; Carter 2002). However, all the results and conclusions obtained do not seem to have penetrated much of the agricultural community in the Mediterranean basin (Carvalho et al. 2002; Cerdà et al. 2017). Frequently, land management still has the same unsustainable characteristics as decades ago. Even this type of unsustainable management also has no impact on political decisions. Public interventions about degradation processes in many places are usually minimal or nil (Requier-Desjardins et al. 2011).

Studies on soil erosion have been carried out to date in almost all possible agricultural systems, whether agricultural or livestock use. There are many works on soil erosion in olive groves (Fleskens \& Stroosnijder 2007; Gómez et al. 2009; Kairis et al. 2013), vineyards (Rodrigo-Comino 2018), fruit trees (Cerdà et al. 2016; Keesstra et al. 2016), or in agrosilvopastoral systems (Schnabel 1997; Rubio-Delgado et al. 2018). However, studies that address soil erosion in chestnut crops are very few. There are some in Kazakhstan (Shokparova et al. 2014), and other works that only mention the existing problem.

The risk of chestnut disappearance in southern areas due to climate change is increasingly likely. If this situation is increased by the location of the chestnut crop on very steep slopes, there is a need to quantify and monitor the progression of these types of crops in Extremadura.

The main aim of this work is to quantify the losses by soil erosion in a farm of chestnut trees located on a hillside. The secondary objectives are to compare the amount of loss soil in chestnut with different ages ( $30-35$ and $60-65$ years) and to analyze the difference between areas under trees and in open areas. Our hypothesis is tree cover plays a crucial role preventing soil erosion.

\section{Materials and Methods}

\subsection{Study area}

The mean altitude of study area ranges from 437 to $1,437 \mathrm{~m}$ a.s.l. (Fig. $1 \mathrm{~A}$ and $1 \mathrm{~B}$ ) and the mean slope of $16^{\circ}$ (Fig. 2). The soil type that predominates in the study area can be referred to as an Entisol Orthent (USDA Taxonomy). It is a characteristic soil of recently eroded surfaces, located on unstable slopes that do not allow soil development. For this study, the chestnut plantation selected is located in the natural region of the Villuercas (Extremadura, SW Spain), in the heart of the Geopark Villuercas-Ibores-Jara (UNESCO World Heritage Site). It is a place where this type of crops is traditionally predominant over others (such as the cultivation of the olive grove), but where the lack of information on soil losses is very significant.

The chestnut trees are located in a field $3 \mathrm{~km}$ from the municipality of Navezuelas (Cáceres), known by the name of El Pilangrón. This farm was selected for presenting the characteristic patterns of this type of plantation in the surrounding area, i.e. steep slopes typical of the predominant Appalachian relief. The total annual average rainfall reaches $1,000 \mathrm{~mm}$ and the average annual temperature is $16.6^{\circ} \mathrm{C}$ (Guadalupe meteorological station, REDAREX, $39^{\circ} 23^{\prime} 13^{\prime \prime} \mathrm{N}, 05^{\circ} 20^{\prime} 53^{\prime \prime} \mathrm{W}$ ). The climate is Mediterranean of type Csa according to the Köppen climate classification (Köppen \& Geiger 1930), characterized by cold months like January with an average temperature of $7{ }^{\circ} \mathrm{C}$ and very hot months like July with an average temperature of $26^{\circ} \mathrm{C}$. December $(150.0 \mathrm{~mm})$ and August $(7.9 \mathrm{~mm})$ are the wettest and driest months, respectively.

Trees were planted in the 1960s and 1990s (Fig. 1C) following a spatial pattern of $12 \times 12$ meters of distance between them to facilitate the different tasks that are practiced on the farm. In Navezuelas, since the nineteenth century the feet of chestnut trees are of the reboldos chestnut variety in which the graft of the verata variety is later performed (synonymous with Injerta de 


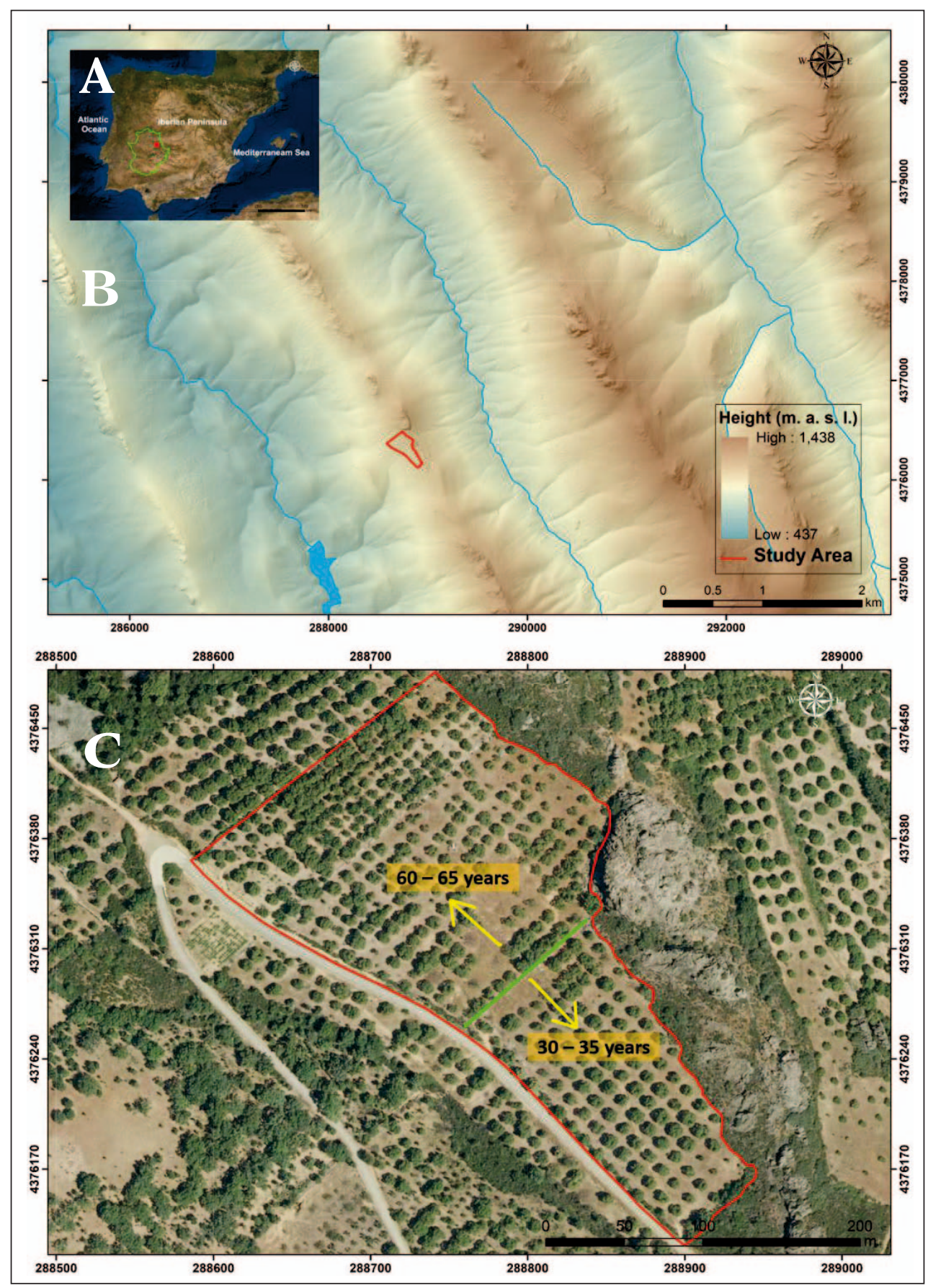

Fig. 1. Location of the study area (A), topographic elevations and changes (B) and distribution of chestnut trees plantation (C).

Navezuelas). The age at which chestnut trees start to produce varies between grafted trees and those that are not. Normally, ungrafted trees produce chestnuts in around 10 years while the graft starts in 5 or 6 years. Traditionally, reboldos chestnuts are grafted between 15 or 20 years old in Navezuelas. However, this kind of graft it has worse consequences than if the graft is done when the trees are 2 or 3 years old. This is mainly due to the fact that wounds caused by external agents (e.g. broken branches) are more difficult to heal on the feet of reboldos chestnuts that have been grafted later (personal communication with the owner).

\subsection{Experimental design}

For the experimental design, the two different types of chestnut age were considered [i.e., chestnuts planted in 1960s (A) and 1990s (B)]. A total of 18 erosion plots were installed randomly in pairs and taking into account two locations: under tree canopies and in open areas. In A: 4 under two canopies and 4 in open areas; in B: 6 under three canopies and 4 in open spaces. Erosion plots have a size of $2 \mathrm{~m}^{2}, 2 \mathrm{~m}$ in length and $1 \mathrm{~m}$ in width (Figs. 3 and 4). The height of the metallic material that acts as the edge of the plot is $10 \mathrm{~cm}$ high. Each plot in its lower 


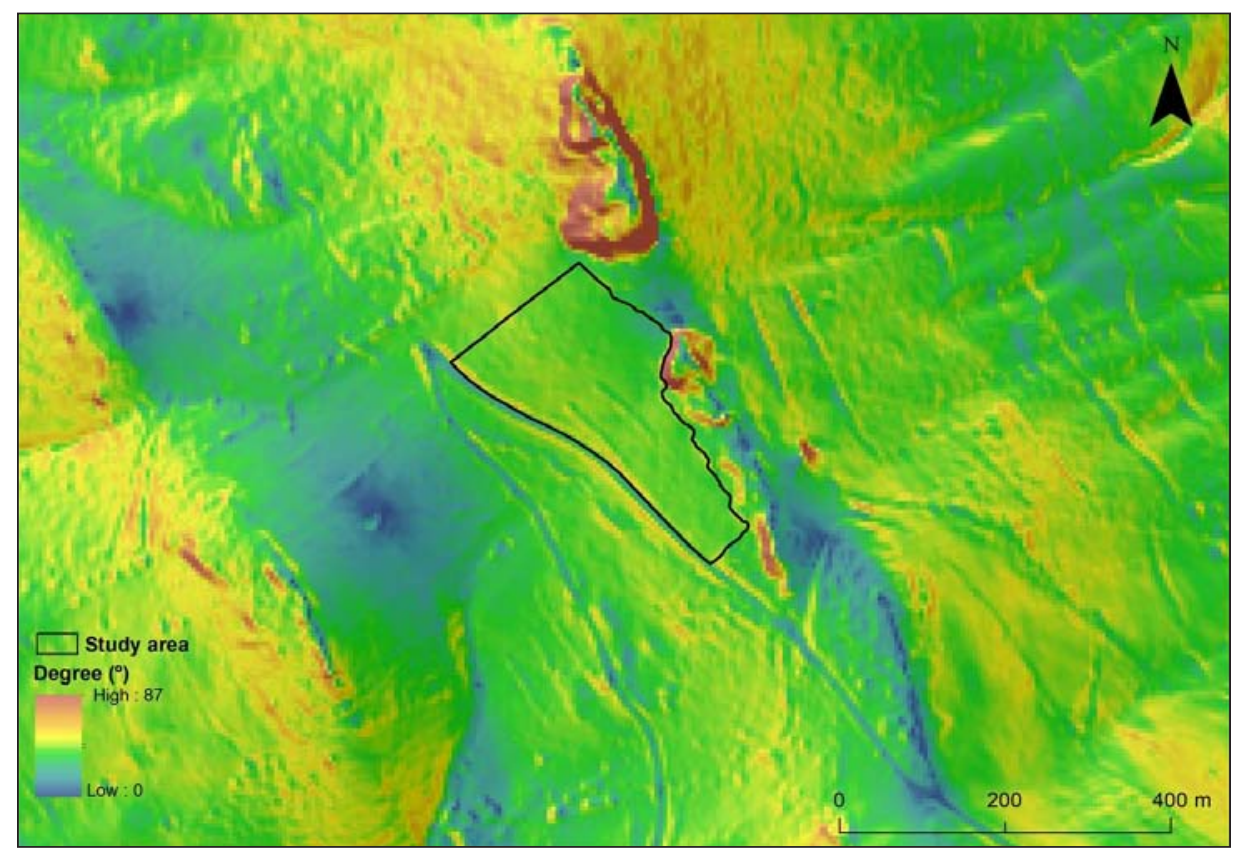

Fig. 2. Slope map of the study area and surroundings.

area has a collector that connects with a 25 litres bottle where the amount of water and deposits generated by the rain event is stored.

Measurements are made after each rain event. In each of the measurements, the accumulated rain is recorded in the pluviometer installed in the farm and it is using the data of Guadalupe meteorological station too. The percentage of bare soil and the percentage of tree cover in each plot was quantified through a visual estimate (Antoneli et al. 2018). Quantification measurements of bare soil and tree cover are always carried out by the same person. Water with or without sediments accumulated in the 25 litres carafe is deposited in precipitation vessels that are subsequently taken to the laboratory to quantify

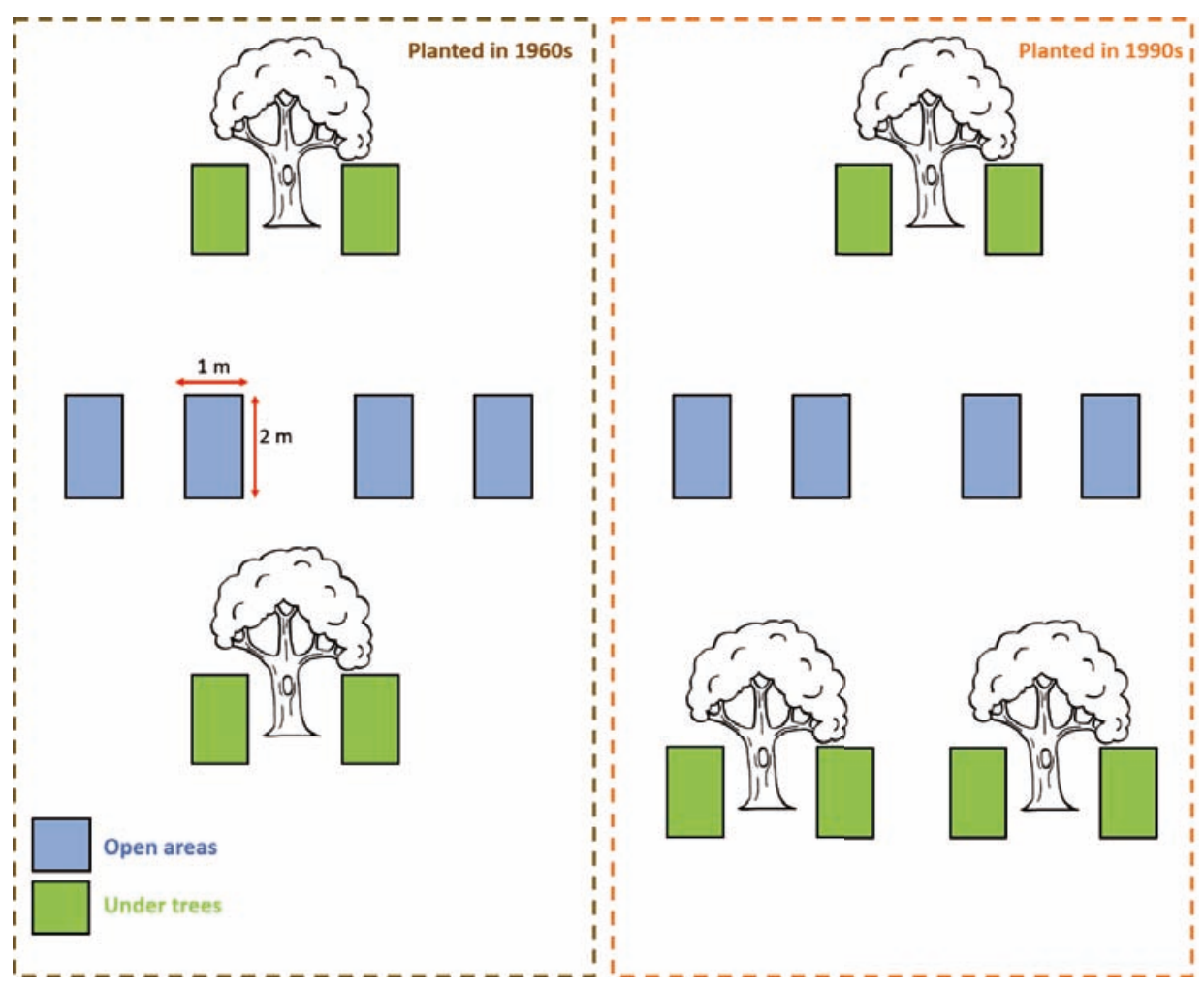

Fig. 3. Distribution and size of erosion plots on the farm. 
the volume of accumulated sediments. The precipitation vessels are weighed and then put in an oven at $105^{\circ} \mathrm{C}$ for 24 hours. Once all the water in the precipitation vessel has evaporated, the vessel is reweighed to calculate the volume of sediments $\left(\mathrm{g} / \mathrm{m}^{2}\right)$. The runoff coefficient is measured taking into account the total rainfall of the event and the amount of water collected in the carafe.

\subsection{Data analysis}

For the statistical analysis, the mean and standard deviation were used in each of the variables studied to compare the results. For the study of the evolution of the bare soil, tree cover and quantification of the soil losses, the means with error plots graphs were used. In these graphs, appear the whiskers ( \pm 1 Standard Deviation), Kruskal-Wallis test and F test, p (ANOVA). For the cor- relation between soil losses and total rainfall per event, the scatterplot graphs were used, where the correlation coefficient ( $r$ ) and the Spearman correlation (p) appear. Statistical analysis was carried out by using Statistica 6.0 software.

\section{Results}

\subsection{Rainfall characterization}

Figure 5 shows the climate graph for the period studied. The total accumulated rainfall per month is shown on the bar chart and the average temperature in the same period appears on the line chart. In the climate graph, a distinction is made between the two periods studied so far. The 2018/2019 period (one full year) and the 2019/2020 period (4 months). The total accumulated rainfall in the first period (2018/2019) is $645 \mathrm{~mm}$, when the average

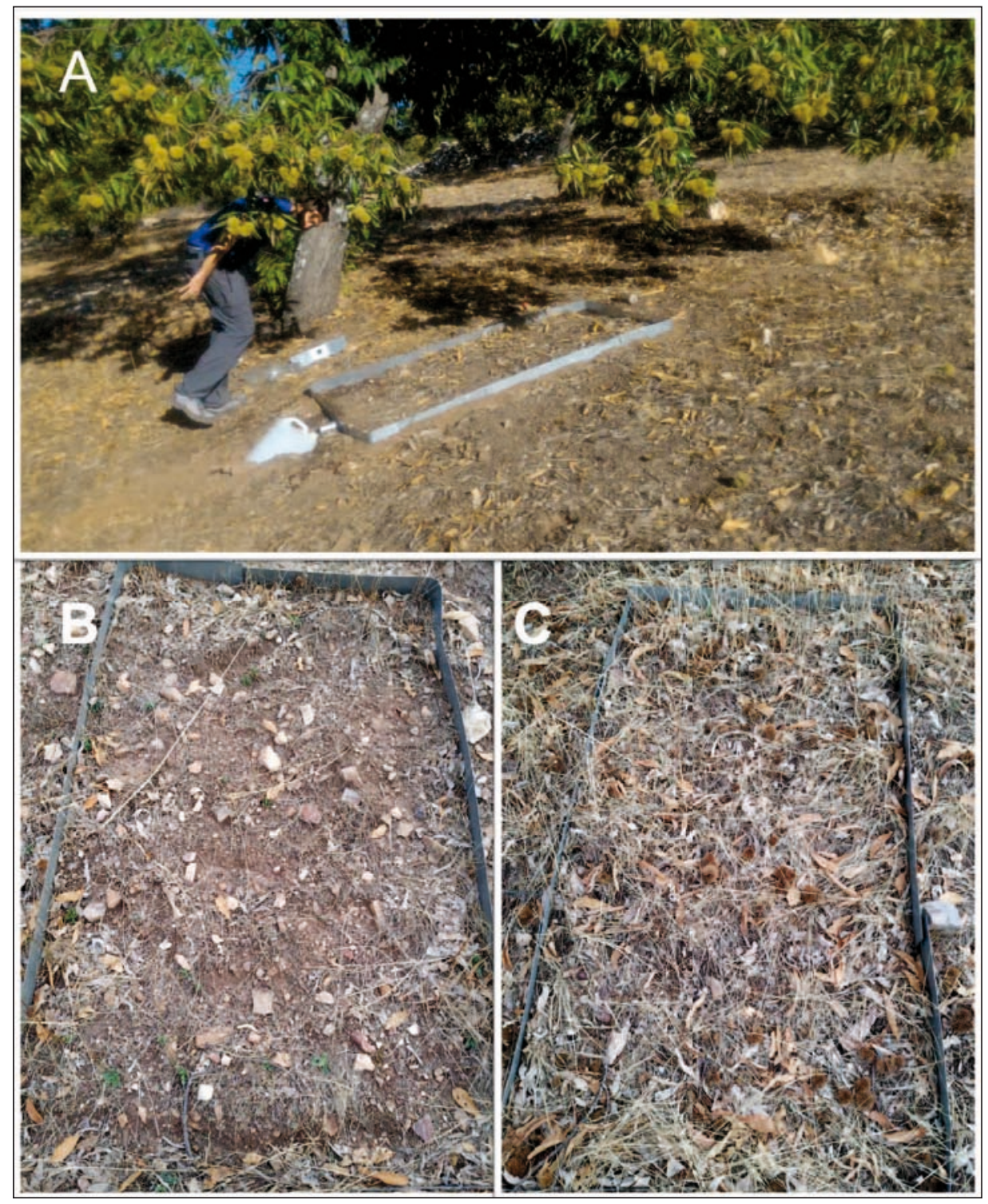

Fig. 4. Some plots during installation (A), open area (B) and under tree (C). 
annual rainfall for a series of 12 -year data (data available at the Guadalupe meteorological station) is $905 \mathrm{~mm}$, a difference $260 \mathrm{~mm}$.

According to the climatic seasons, in the 2018/2019 period the greatest amount of rainfall is concentrated in the autumn months $(288 \mathrm{~mm})$ while in the data series, the rainiest months are those of winter. The average rainfall in these months is $346 \mathrm{~mm}, 176 \mathrm{~mm}$ more than in the winter months recorded in the first period $(170 \mathrm{~mm})$. In general, in all months of the period rainfall values are recorded below those of the series, except for the months of October and November (124 and $163 \mathrm{~mm}$, respectively), 11 and $68 \mathrm{~mm}$ more than in the data series in the same months.

In terms of temperature, the difference between the first period and the data series is $0.4{ }^{\circ} \mathrm{C}$, higher in the studyyear $2108 / 2019$ than in the data series $\left(16.1^{\circ} \mathrm{C}\right.$ and $15.7^{\circ} \mathrm{C}$, respectively). In the second period (2019/2020), precipitation data, in general, is below the average of the series data in the same months, with a difference in the autumn season that reaches $55 \mathrm{~mm}$.

Table 1 shows the total rainfall accumulated in Guadalupe station per each events and the accumulated rainy days. The greatest rainfall is mainly concentrated in the autumn and winter months. In general, rain events are reduced during spring and summer although some important event appears during the month of April and May (events 15 - 16) that exceed $50 \mathrm{~mm}$. On the other hand, the most important rain events (5-11-25 events) have been recorded during the autumn and winter, registering a total rain of $80.2,101.1$ and $220.5 \mathrm{~mm}$ respectively.

\subsection{Bare soil}

Fig. 6 shows the average percentage of bare soil measured in the plots in each of the events. In general, bare soil follows a pattern related to seasonality depending on the time of year. In this case, the time of the highest percentage of bare soil in the chestnut soils coincides with the end of summer and, practically, all of autumn (see Table 1). During the period between late summer and early autumn, the soil surface is cleaned of leaves and branches in order to condition it to the chestnut harvest. Hence, during all this time there is a percentage of bare soil above $50 \%$. However, as of November the percent- age of bare soil begins to reduce considerably, reaching a percentage less than more than $25 \%$ (58.2\% event 2 and $31.4 \%$ event 16 ). This stage initially coincides with the leaf fall of the trees that causes the soil to cover almost entirely of fallen leaves and some broken branches due to the natural pruning of the tree. And later, with the beginning of spring and the growth of all the grass marshmallows that grow during this time.

\subsection{Tree cover}

Fig. 7 shows the soil surface (\%) covered by tree canopies. There are two different stages in the evolution of the percentage of tree cover. On one hand, we have found percentage values that are above $70-80 \%$. These data coincide with the period of greater foliation of the chestnut, just before or during the time of the harvest (autumn months). However, we find other values quite lower than those aforementioned. These values that barely exceed $40 \%$ in some close to $20 \%$ corresponds to the winter stage. During this time, the tree loses the leaf in its entirety and it is not until the spring months when it begins again to reach higher foliation values. In addition to these two extreme moments, we find two transition stages that correspond, at first with the end of autumn and start of winter, and in a second moment, with the start of spring and the end of summer.

\subsection{Soil losses}

Figure 8 shows the sum of the average in $\mathrm{g} \mathrm{m}^{-2}$ of all the plots distributed under tree and in open areas in plantations of different ages for the two study periods. There are 4 plots for each of the variables represented, except in the under tree plots of 1990s plantation where there are a total of 6 plots (see Fig. 2). We can see that there is an obvious difference between the two periods studied, due to the difference in the events recorded in one year and another. However, there are differences between soil losses recorded under trees and open areas and between the two plantations. For the first year of study, soil losses in plots in open areas of the 1960s plantation reach $51.3 \mathrm{~g} \mathrm{~m}^{-2}$ while in the $1990 \mathrm{~s}$ plantation they reach $86.5 \mathrm{~g} \mathrm{~m}^{-2}$, a difference of more than $30 \mathrm{~g} \mathrm{~m}^{-2}$.

This situation is repeated in the second year of study with values for the plantation of 1960 and 1990 that reach

Table 1. Characterization of the rain events measured in $\mathrm{mm}$.

\begin{tabular}{|c|c|c|c|c|c|c|c|c|}
\hline Event & Date $(*)$ & Rainfall & Event & Date & Rainfall & Event & Date & Rainfal \\
\hline 2 & 2018-10-19 (7) & 66.2 & 10 & $2018-01-20(3)$ & 25.2 & 18 & 2019-09-22(11) & 16.5 \\
\hline 3 & $2018-10-28(5)$ & 19.5 & 11 & $2019-02-02(5)$ & 101.1 & 19 & 2019-10-19(4) & 17.0 \\
\hline 4 & $2018-10-29(2)$ & 38.2 & 12 & 2019-02-14 (2) & 3.6 & 20 & $2019-10-26(2)$ & 19.9 \\
\hline 6 & $2018-11-23(8)$ & 35.5 & 14 & 2019-03-09 (4) & 26.6 & 22 & 2019-11-16 (3) & 11.4 \\
\hline 7 & $2018-11-25(2)$ & 37.6 & 15 & 2019-04-12 (8) & 56.9 & 23 & $2019-11-23(4)$ & 54.3 \\
\hline 8 & 2018-12-13 (7) & 33.7 & 16 & $2019-05-01(8)$ & 77.4 & 24 & 2019-12-06 (8) & 37.1 \\
\hline
\end{tabular}

* Rainy days. 


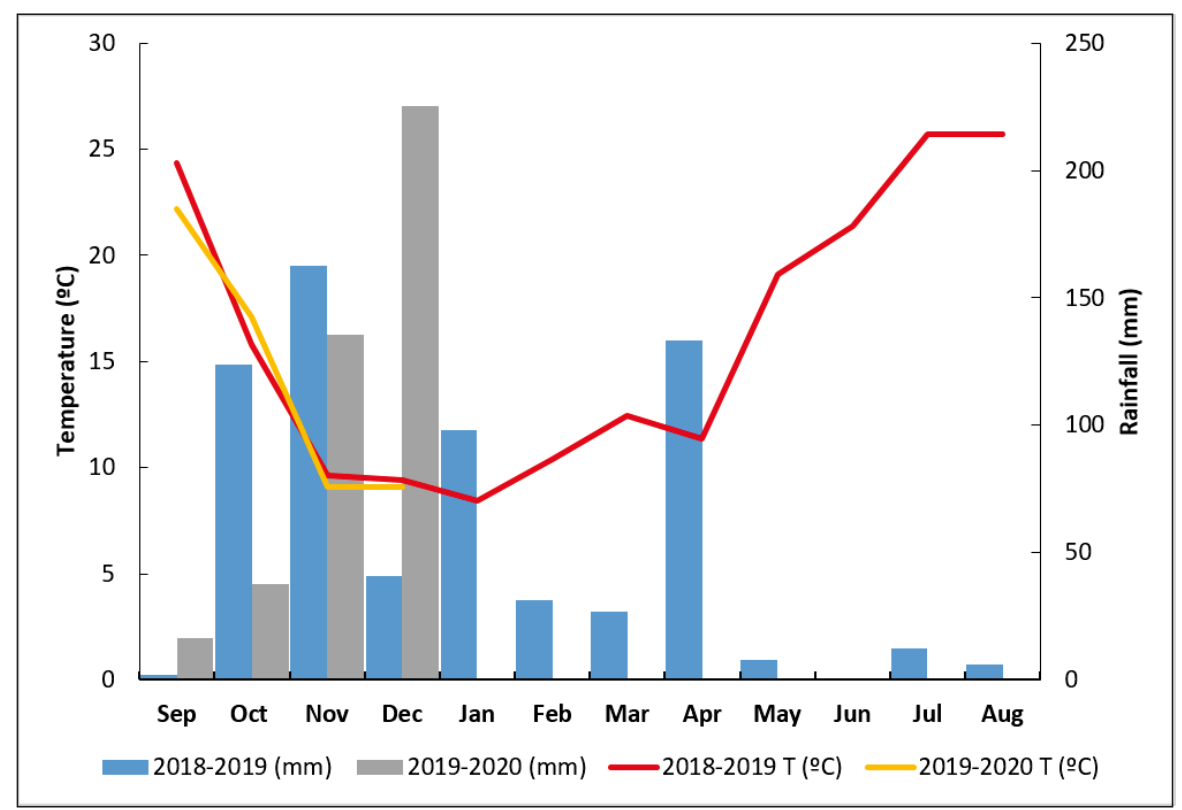

Fig. 5. Climate graph for the period studied. On the left axis the temperature is represented and on the right axis the rain. The blue bars and the red line represent the 2018/2019 data period and the gray bars and the yellow line the 2019/2020 period.

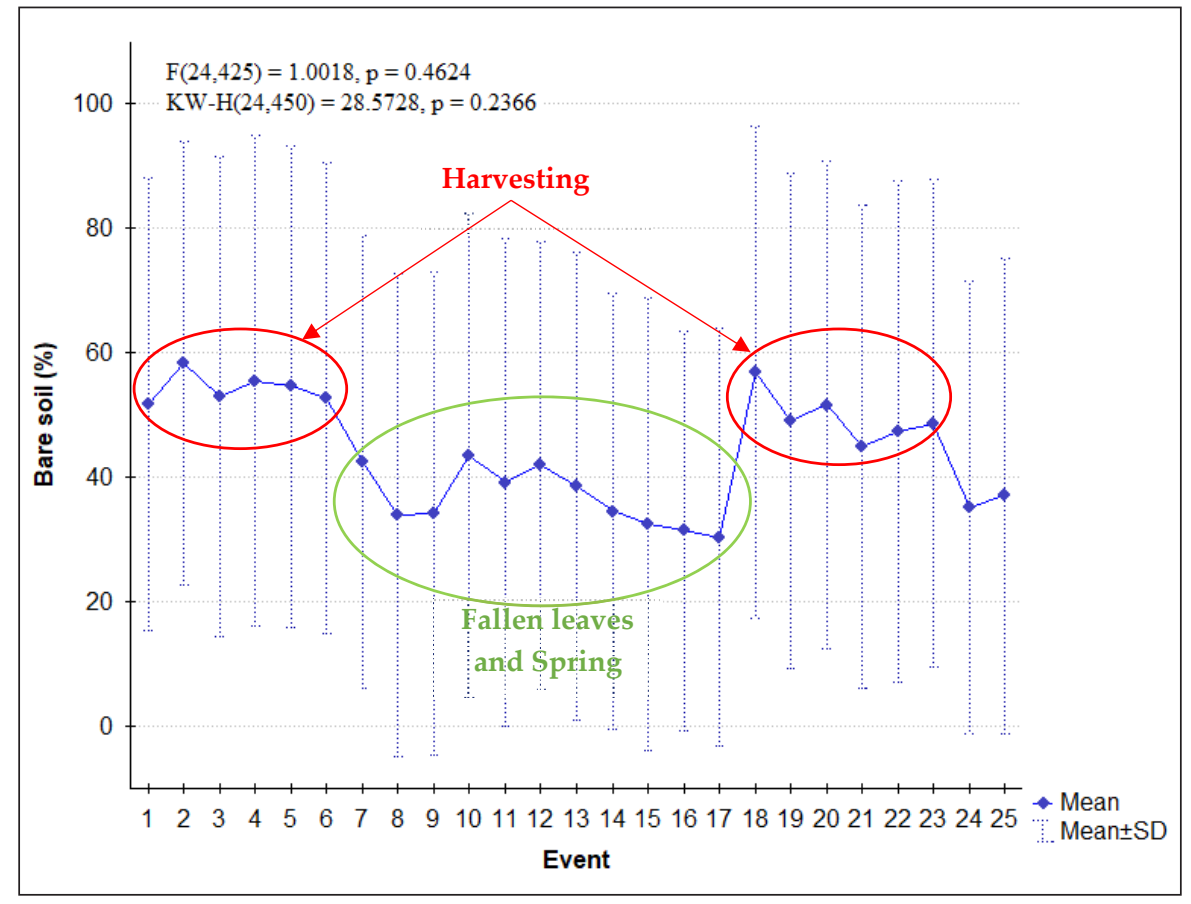

Fig. 6. Evolution of percent of bare soil per events. The solid line indicates the mean and the dashed lines (whiskers) indicate the mean \pm 1 standard deviation.

soil losses of $13.1 \mathrm{~g} \mathrm{~m}^{-2}$ and $34.6 \mathrm{~g} \mathrm{~m}^{-2}$, respectively. Regarding soil losses registered under tree soil erosion is reduced considerably, as if we compare between plantations with different ages. In the first year of the study, in the plots under tree of the plantation of 1960 losses of soil of $7.3 \mathrm{~g} \mathrm{~m}^{-2}$ were registered while in the plots of the plantation of 1990 they reached $13.5 \mathrm{~g} \mathrm{~m}^{-2}$. In the sec- ond year of study, the same situation was recorded as in the first year although the volume of soil loss was lower ( $4.8 \mathrm{~g} \mathrm{~m}^{-2}$ and $2.8 \mathrm{~g} \mathrm{~m}^{-2}$, respectively). The instability of the soil in the youngest plantation and the greater tree cover of the oldest plantation play a fundamental role in the loss of soil. 


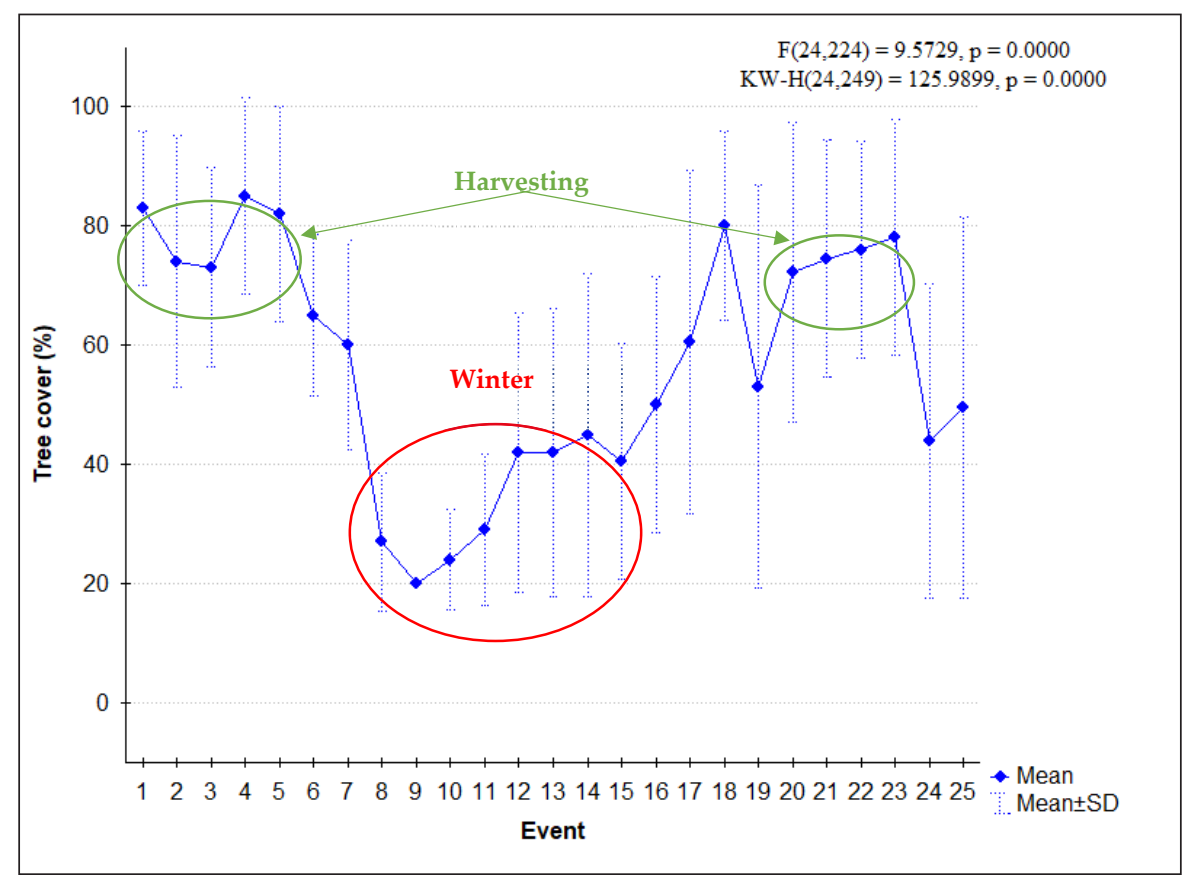

Fig. 7. Evolution of percent of tree cover per events. The solid line indicates the mean and the dashed lines (whiskers) indicate the mean \pm 1 standard deviation.

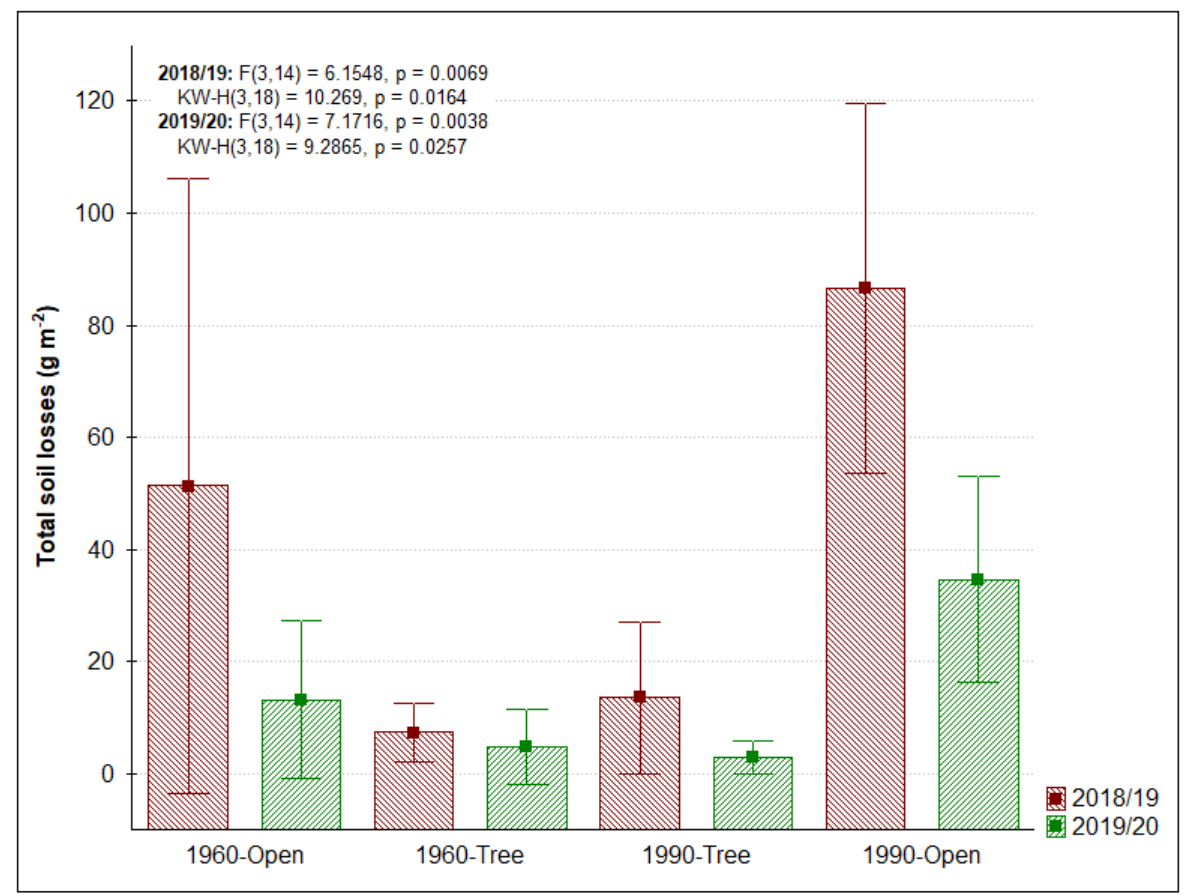

Fig. 8. Total of soil losses in plots under tree and in open areas in plantations of different ages in the period studied (2018-2019 / 2019 - 2020).

\subsection{Correlation analysis}

Table 5 shows the correlation coefficient between the variables studied. The bare soil shows a high negative correlation with the tree cover $(\mathrm{r}=-0.567, \mathrm{p}<0.001)$. However, bare soil show a high positive correlation with soil losses $(r=0.531, p<0.001)$. It also shows a significant positive correlation with runoff and sediment concentration $(r=0.475$ and $r=0.310, p<0.001$, respectively). Interestingly, soil losses also show a negative correlation with tree cover $(r=-0.276, p<0.001)$. In turn, soil losses have a high correlation with runoff and sediment concentration $(r=0.813$ and $r=0.745, p<0.001$, respectively). 
Table 2. Spearman's correlation coefficients between soil erosion parameters, rainfall, bare soil and tree cover percentage and sediment concentration.

\begin{tabular}{|c|c|c|c|c|c|}
\hline & Rainfall & Bare soil & Tree cover & Runoff & $\begin{array}{c}\text { Sediment } \\
\text { concentration }\end{array}$ \\
\hline Bare soil & -0.010 & & & & \\
\hline Tree cover & -0.002 & $-0.567 * * *$ & & & \\
\hline Runoff & $0.190 * * *$ & $0.475^{* * *}$ & $-0.344 * * *$ & & \\
\hline Sediment & $0.140 *$ * & $0.310^{* * *}$ & -0.096 & $0.403 * * *$ & \\
\hline Soil losses & $0.245 * * *$ & $0.531 * * *$ & $-0.276^{* * *}$ & $0.813 * * *$ & $0.745 * * *$ \\
\hline
\end{tabular}

Fig. 9 shows the scatterplot between soil losses and volume of rainfall recorded by events. The correlation that exists between soil losses and the amount of rainfall is not very high $(r=0.149, p=0.002)$. Soil losses in general show values below $20 \mathrm{~g} \mathrm{~m}^{-2}$ in events ranging between 30 and $40 \mathrm{~mm}$. We can see that the same amount of rain can produce more or less erosion.

Figure 10 shows the scatter plot between the values of soil losses and the percentage of bare soil. Soil losses are highly correlated with the percentage of bare soil

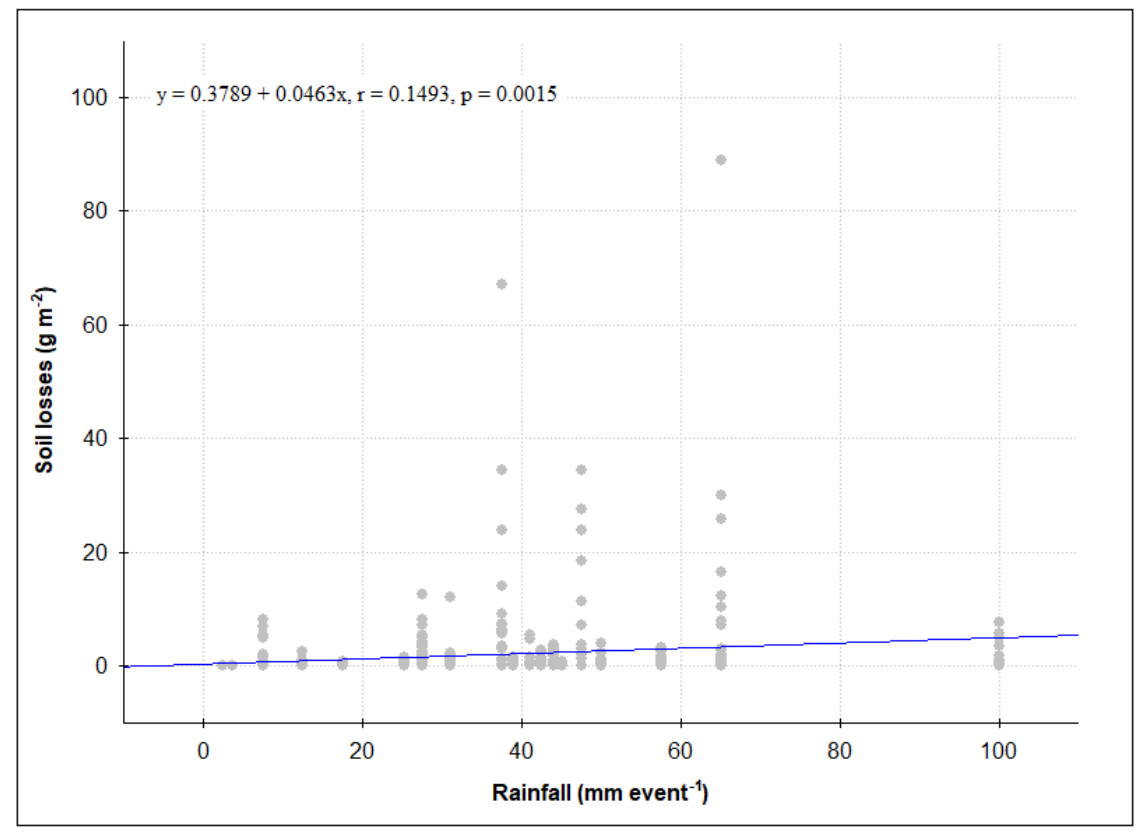

Fig. 9. Correlation between soil losses $\left(\mathrm{g} \mathrm{m}^{-2}\right)$ and the amount of rainfall $\left(\mathrm{mm} \mathrm{event}^{-1}\right)$ per events.

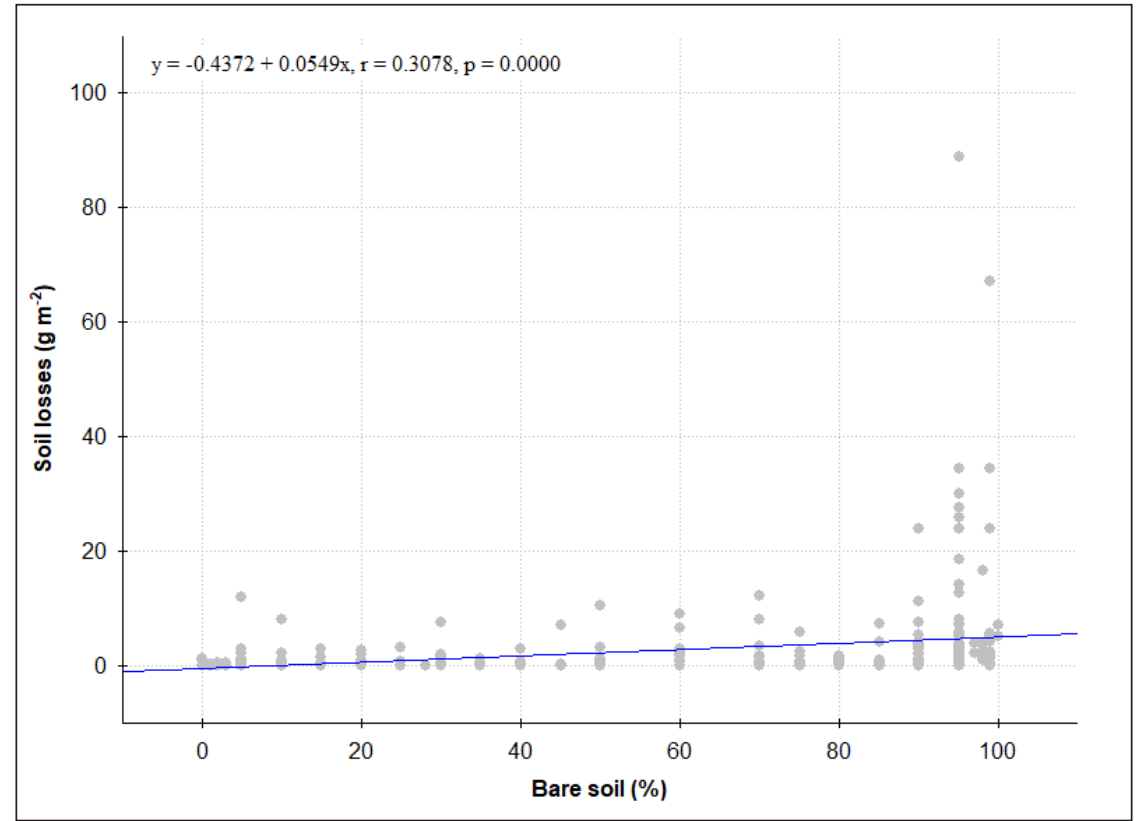

Fig. 10. Correlation between soil losses $\left(\mathrm{g} \mathrm{m}^{-2}\right)$ and percentage of soil loses. 
$(r=0.308, p=0.000)$. As the percentage of bare soil increases, soil losses increase. The values of soil losses rise significantly from percentages of more than $85 \%$ of bare soil.

\section{Discussion}

The results obtained in erosion plots installed in the same farm but with different plantation ages (1960s and 1990s) were compared. In addition, the comparison includes the resulting values of the plots installed in open areas and under tree. Bare soil values show a regular trend along something. In chestnuts the highest values of bare soil (more than 50\%) are concentrated at the end of the summer and during the autumn months. Interestingly, in the case of chestnut trees, the stage with the largest area of bare soil under a tree coincides with the moment of greatest foliation of chestnut tree. The main reason for this situation is mainly due to the cleaning of the soil in late summer and early autumn to facilitate the collection of chestnuts. The cleaning of the soil is carried out in different ways, by grazing, using herbicides or eliminating all herbaceous cover under tree with rakes.

Tree cover evolution values follow a similar trend to those of bare soil. It is in the harvest months where the highest tree cover values were recorded, being the lowest during the winter. The action exerted by the tree as an interceptor of raindrops in these cases is essential, reducing the volume of precipitation that reaches the ground as demonstrated by Mateos \& Schnabel (2013). Since in this case the largest volume of bare soil coincides with the maximum tree cover a clear balance between parts appear. Thus, cleaning the soil under a tree does not seem to be an unsustainable practice of soil erosion management, in terms of splash erosion effects.

The greatest losses of soil were recorded in open areas with values that reach $86.5 \mathrm{~g} \mathrm{~m}^{-2}$, values that differ many of those found by Guzmán et al. (2013) in an olive grove crop between rows $\left(1.4 \mathrm{~kg} \mathrm{~m}^{-2}\right)$. In addition, the rates of soil loss are higher in the younger plantation than in the oldest one demonstrated by Rodrigo Comino et al. (2017) in a vineyard farm. The lowest soil erosion values were measured in plots under a tree, reaching a maximum soil loss of $13 \mathrm{~g} \mathrm{~m}^{-2}$ in the 1990s plantation. As Cerdà et al. (2019) showed, vegetation plays an essential role in soil erosion, exponentially reducing soil losses throughout the year. In other soil erosion studies, rates are higher than those found in chestnut trees, as Comino et al. (2016) found in vineyards in Spain and Germany, as a result of increased tillage and the lack of herbaceous cover due to the application of herbicides. However, these soil erosion rates are considerably reduced in abandoned agricultural areas, as Cerdà et al. (2018) demonstrated in mountainous areas of the Mediterranean, where the disappearance of tillage and the appearance of herbaceous cover were the key factors. Something similar can occur in our study area where the advance of cistus ladanifer occupying a large part of the plot could reduce the effects of water erosion.

The losses of soil and the volume of rains by events did not show a high correlation $(r=0.149)$. In our case, the same amount of rainfall produces the same erosion rates. However, in other studies it has been shown that the increase in the volume of rains causes an increase in soil losses as demonstrated by Arnaez et al. (2007) or Mohamadi \& Kavian (2015) comparing different rainfall intensities. This situation leads us to consider that soil losses with similar behavior are determined by other factors.

The percentage of bare soil and soil losses show a greater correlation $(r=0.307)$ than previous variables. In this study, loss of soil may be greater than other studies, e.g. Antoneli et al. (2018) because the percentage of bare soil is high. Antoneli et al. (2018) found soil losses in different pastures type that ranged between $10 \mathrm{~g} \mathrm{~m}^{-2}$ and $20 \mathrm{~g} \mathrm{~m}^{-2}$, with a percentage of bare soil between from 9 to $24 \%$, soil losses increased when percentage of bare soil exceeds $30 \%$. Nevertheless, in our study, below $85 \%$ of bare soil, the soil losses did not exceed of $20 \mathrm{~g} \mathrm{~m}^{-2}$, while above $85 \%$ of bare soil, soil losses exceed of $30 \mathrm{~g} \mathrm{~m}^{-2}$. A high soil exposure accelerates degradation processes causing the loss of other vital functions of the soil such as nutrient recycling.

\section{Conclusions}

In the southern chestnut trees located in Extremadura, the greatest losses of soil were recorded in open areas and in the youngest chestnut plantation. The tree protects the soil by acting as a protective shield against the impact of raindrops, providing the soil with a layer of leaf litter that helps curb the effects of water erosion. The larger size of the tree canopy and better soil stability in older plantations helps reduce soil losses. The highest percentage of bare soil in southern chestnut trees coincides with the moment of greatest tree cover, creating a balance between parts. However, the results indicate that soil losses increase as the percentage of bare soil increases. Given this situation, the cleaning of the soil under the trees should be avoided during the harvest as suggestion, trying to have the soil covered with vegetation through the year. Nonetheless, further research (installation of Gerlach troughs and a gauging station) and a longer series of data are still needed in order to draw definitive conclusions.

\section{Acknowledgments}

We would like to thank Lope Pulido (owner) for allowing us to install all the necessary material to carry out this research and future ones. Also thank the Regional Government of Extremadura for funding the Jesus PhD scholarship (PD 18016). This 
work has been financially supported by the research Project IB16052 "Desarrollo de un Sistema de evaluación integral espacialmente distribuido para explotaciones de ganadería extensiva" founded by Junta de Extremadura and European Found of Regional Development (European Union).

\section{References}

Antoneli, V., Rebinski, E. A., Bednarz, J. A., RodrigoComino, J., Keesstra, S. D., Cerdà, A. et al., 2018: Soil Erosion Induced by the Introduction of New Pasture Species in a Faxinal Farm of Southern Brazil. Geosciences, 8:166.

Arnaez, J., Lasanta, T., Ruiz-Flaño, P., Ortigosa, L., 2007: Factors affecting runoff and erosion under simulated rainfall in Mediterranean vineyards. Soil and Tillage Research, 93:324-334.

Carter, M. R., 2002: Soil quality for sustainable land management. Agronomy Journal, 94:38-47.

Carvalho, T. M. M., Coelho, C. O. A., Ferreira, A. J. D., Charlton, C.A., 2002: Land degradation processes in Portugal: farmers' perceptions of the application of European agroforestry programmes. Land Degradation \& Development, 13:177-188.

Centeno, G. F., Pérez, S. F. O., de Borbón, C. M. M., 1998: Economía del castaño (Castanea sativa Mill.) en España. Revista forestal española: RFE.(18):11-21.

Cerdà, A., Ackermann, O., Terol, E., Rodrigo-Comino, J., 2019: Impact of Farmland Abandonment on Water Resources and Soil Conservation in Citrus Plantations in Eastern Spain. Water, 11:824.

Cerdà, A., González-Pelayo, Ó., Giménez-Morera, A., Jordán, A., Pereira, P., Novara, A. et al., 2016:. Use of barley straw residues to avoid high erosion and runoff rates on persimmon plantations in (Eastern) (Spain) under low frequency-high magnitude simulated rainfall events. Soil Research, 54:154-165.

Cerdà, A., Rodrigo-Comino, J., Giménez-Morera, A., Keesstra, S. D., 2017: An economic, perception and biophysical approach to the use of oat straw as mulch in Mediterranean rainfed agriculture land. Ecological Engineering, 108:162-171.

Conedera, M., Krebs, P., 2007: History, present situation and perspective of chestnut cultivation in Europe. In: II Iberian Congress on Chestnut 784. [place unknown]; p. 23-28.

Conedera, M., Krebs, P., Tinner, W., Pradella, M., Torriani, D., 2004: The cultivation of Castanea sativa (Mill.) in Europe, from its origin to its diffusion on a continental scale. Vegetation History and Archaeobotany, 13:161-179.

Conedera, M., Manetti, M. C., Giudici, F., Amorini, E., 2004: Distribution and economic potential of the Sweet chestnut (Castanea sativa Mill.) in Europe. Ecologia Mediterranea, 30:179-193.
Conedera, M., Tinner, W., Krebs, P., de Rigo Daniele, Caudullo Giovanni, 2016: Castanea sativa in Europe: distribution, habitat, usage and threats. In: SanMiguel-Ayanz, J., de Rigo, D., Caudullo, G., Houston Durrant, T., Mauri, A. (eds.): European Atlas of Forest Tree Species [Internet]. Luxembourg: Publication Office of the European Union; [accessed $2020 \mathrm{Apr}$ 1]; p. 78-79. https://w3id.org/mtv/FISE-Comm/ $\mathrm{v} 01 / \mathrm{e} 0125 \mathrm{e} 0$

Doran, J. W., Zeiss, M.R., 2000: Soil health and sustainability: managing the biotic component of soil quality. Applied Soil Ecology, 15:3-11.

Dregne, H. E., 1986: Desertification of arid lands. In: Physics of desertification. [place unknown]: Springer; p. 4-34.

Fleskens, L., Stroosnijder, L., 2007: Is soil erosion in olive groves as bad as often claimed? Geoderma, 141:260-271.

García-Ruiz, J. M., 2010: The effects of land uses on soil erosion in Spain: A review. Catena, 81:1-11.

Gómez, J.A., Sobrinho, T. A., Giráldez, J.V., Fereres, E., 2009: Soil management effects on runoff, erosion and soil properties in an olive grove of Southern Spain. Soil and Tillage Research, 102:5-13.

González, I. A., Barrero, M. C. A., Bañuls, P., Correa, F., Manzano, M.A. et al., 2013: Estado sanitario de los castañares de los valles del Jerte y de La Vera (Norte de Extremadura). Phytoma España: La revista profesional de sanidad vegetal,(245):38.

Griggs, D., Stafford-Smith, M., Gaffney, O., Rockström, J., Öhman, M. C., Shyamsundar, P. et al., 2013: Policy: Sustainable development goals for people and planet. Nature, 495:305.

Guzmán, G., Vanderlinden, K., Giráldez, J. V., Gómez, J.A., 2013: Assessment of spatial variability in water erosion rates in an olive orchard at plot scale using a magnetic iron oxide tracer. Soil Science Society of America Journal, 77:350-361.

Kairis, O., Karavitis, C., Kounalaki, A., Salvati, L., Kosmas, C., 2013: The effect of land management practices on soil erosion and land desertification in an olive grove. Soil Use and Management, 29:597-606.

Keesstra, S., Pereira, P., Novara, A., Brevik, E. C., Azorin-Molina, C. et al., 2016: Effects of soil management techniques on soil water erosion in apricot orchards. Science of the Total Environment, 551:357-366.

Keesstra, S. D., Bouma, J., Wallinga, J., Tittonell, P., Smith, P., Cerdà, A. et al., 2016: The significance of soils and soil science towards realization of the United Nations Sustainable Development Goals. Soil.

Köppen, W., Geiger, R., 1930: Handbuch der klimatologie. [place unknown]: Gebrüder Borntraeger Berlin.

Lal, R., 2001: Soil degradation by erosion. Land Degradation \& Development, 12:519-539. 
MacDonald, D., Crabtree, J. R., Wiesinger, G., Dax, T., Stamou, N., Fleury, P. et al., 2000: Agricultural abandonment in mountain areas of Europe: environmental consequences and policy response. Journal of Environmental Management, 59:47-69.

Manuel Berrocal del Brío JFG y JMCH. 1998. El castaño. Productor de frutoy madera. Creador de paisajey protector. [place unknown]: Mundiprensa.

Martín, M. A., Dorado, J., Platero, M., Solla, A., Martín, L. M., 2017. Las variedades tradicionales de castaño en Extremadura: identificación y caracterización. In: $7^{\circ}$ Congreso Forestal Español Plasencia. [place unknown].

Martín, M. A., Moral, A., Martín, L. M., Alvarez, J. B., 2007: The genetic resources of European sweet chestnut (Castanea sativa Miller) in Andalusia, Spain. Genetic Resources and Crop Evolution, 54:379-387.

Mateos, B., Schnabel, S., 2013: Rainfall interception by Holm Oaks in Mediterranean open woodland. Cuadernos de Investigación Geográfica, 27:27-38.

Meira Cartea, P. Á., 2007: Comunicar el cambio climático: escenario social y líneas de acción. [place unknown]: Ministerio de Medio Ambiente y Medio Rural y Marino.

Millán, M. M., Estrela, M. J., Sanz, M. J., Mantilla, E., Martín, M., Pastor, F. et al., 2005: Climatic feedbacks and desertification: the Mediterranean model. Journal of Climate, 18:684-701.

Mohamadi, M. A., Kavian, A., 2015: Effects of rainfall patterns on runoff and soil erosion in field plots. International Soil and Water Conservation Research, 3:273-281.

Montgomery, D. R., 2007: Soil erosion and agricultural sustainability. Proceedings of the National Academy of Sciences, 104:13268-13272.

Pimentel, D., Harvey, C., Resosudarmo, P., Sinclair, K., Kurz, D., McNair, M. et al., 1995: Environmental and economic costs of soil erosion and conservation benefits. Science, 267:1117-1123.
Pulido, F., Sanz, R., Abel, D., Esquerra, J., Gil, A., González, G. et al., 2007: Los bosques de Extremadura: Evolución, ecología y conservación.

Renwick, A., Jansson, T., Verburg, P. H., Revoredo-Giha, C., Britz, W., Gocht, A., McCracken, D., 2013: Policy reform and agricultural land abandonment in the EU. Land Use Policy, 30:446-457.

Requier-Desjardins, M., Adhikari, B., Sperlich, S., 2011: Some notes on the economic assessment of land degradation. Land Degradation \& Development, 22:285-298.

Rodrigo-Comino, J., 2018: Five decades of soil erosion research in "terroir". The State-of-the-Art. EarthScience Reviews, 179:436-447.

Rodrigo-Comino, J., Brings, C., Iserloh, T., Casper, M. C., Seeger, M., Senciales, J. M. et al., 2017:Temporal changes in soil water erosion on sloping vineyards in the Ruwer-Mosel Valley. The impact of age and plantation works in young and old vines. Journal of Hydrology and Hydromechanics, 65:402-409.

Rubio-Delgado, J., Schnabel, S., Gómez-Gutiérrez, Á., Sánchez-Fernández, M., 2018: Estimation of soil erosion rates in dehesas using the inflection point of holm oaks. Catena, 166:56-67.

Schnabel, S., 1997: Soil erosion and runoff production in a small watershed under silvo-pastoral landuse (dehesas) in Extremadura, Spain. [place unknown]: Geoforma.

Shokparova, D. K., Kakimjanov, E. K., Meyer, B. C., 2014: Erosion rates depending on slope and exposition of cropped chestnut soils. In: Novel Measurement and Assessment Tools for Monitoring and Management of Land and Water Resources in Agricultural Landscapes of Central Asia. [place unknown]: Springer; p. 549-561.

Statsoft. STATISTICA(Data Analysis Software System), Version 6.2001. Available online: www.statsoft.com (accessed on 15 Jan 2020). 